
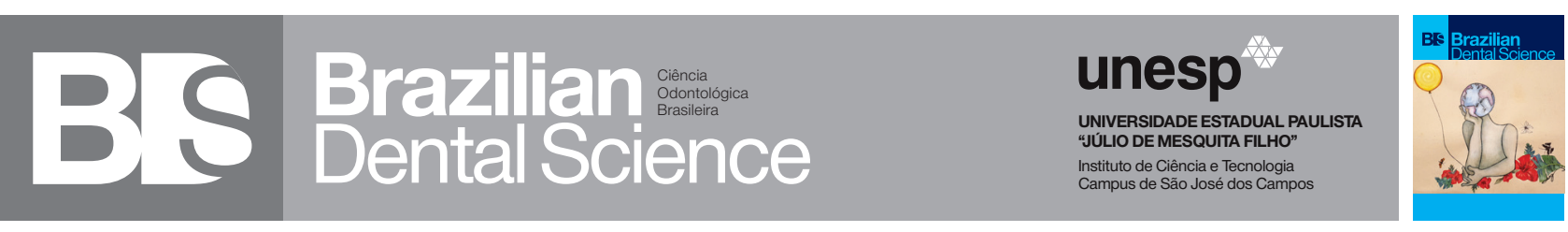

\title{
Management of the maxillary sinus complications after dental implantation: a systematic review and meta-analysis
}

\author{
Tratamento das complicações do seio maxilar após cirurgia de implante dentário: Revisão Sistemática e Meta-Análise \\ Samira JAMALI ${ }^{1}$, Navid NASRABADI ${ }^{2}$, Salar PAYAHOO ${ }^{3}$, Maryam DARVISH ${ }^{4}$, Hashem AHMADIZADEH ${ }^{5}$, Setareh KHOSRAVI ${ }^{6}$ \\ 1 - Department of Endodontics - Stomatological Hospital - College of Medicine - Xi'an Jiaotong University - Shaanxi 710004 - PR China. \\ 2 - Department of Endodontics - School of Dentistry - Shahid Beheshti University of Medical Sciences - Tehran - Iran. \\ 3 - Department of Oral and Maxillofacial Radiology - Dental School - Urmia University of Medical Sciences - Urmia - Iran. \\ 4 - Department of Endodontics - School of Dentistry - Kerman University of Medical Sciences - Kerman - Iran. \\ 5 - School of Dentistry - Tehran University of Medical Sciences - Tehran - Iran. \\ 6 - Department of Orthodontics - Shahed University of Medical Sciences - Tehran - Iran.
}

\section{ABSTRACT}

Background and aim: Endoscopic sinus surgery owing to its satisfactory prognosis and low complication is considered as the first line of surgical procedure. Implant failure is often reported despite efforts in recent years. The purpose of this study was to review the factors leading to side effects in dental implantation of the maxillary sinus. Material and Methods: The systematic search was performed on electronic databases of MEDLINE, PubMed, Cochrane Library, Embase, ISI, Google scholar to find corresponding articles regarding dental literature during 2010 to 2019. Electronic title management was carried out by Endnote X9 software. Searches were based on the keywords of "dental implants", "Implants"," dental"," maxilla", "sinusitis". Results: The searched potentially relevant titles and abstracts were related to 294 articles, 104 of which were excluded due to lack of study inclusion criteria. At last, 11 articles were included into the final analysis. Postoperative sinusitis was found in 78 patients within 9 articles among 1195 patients. The implant failure was reported in 136 cases and the sinus membrane perforation in 185 sinuses within 11 articles among 1372 sinus lift procedures. Conclusion: The findings showed that the risk factors of sinusitis after implant surgery were Schneiderian membrane rupture and preoperative sinusitis, as well as smoking and residual bone height were the parameters elevating the dental implant failure risk.

\section{KEYWORDS}

Sinusitis; Dental implants; Implant failure.

\section{RESUIMO}

Justificativa e objetivo: A cirurgia endoscópica do seio maxilar, devido ao seu prognóstico satisfatório e baixa complicação, é considerada a primeira opção cirúrgica. A falha do implante é frequentemente relatada, apesar dos esforços realizados nos últimos anos. $\mathrm{O}$ objetivo deste estudo foi revisar os fatores que levaram a efeitos colaterais no implante dentário do seio maxilar. Material e Métodos: A busca sistemática foi realizada nas bases de dados eletrônicas do MEDLINE, PubMed, Cochrane Library, Embase, ISI, Google Scholar para encontrar artigos correspondentes sobre literatura odontológica no período de 2010 a 2019. O gerenciamento eletrônico de títulos foi realizado pelo software Endnote X9. As pesquisas foram baseadas nas palavras-chave "implantes dentários", "implantes", "dentário", "maxila", "sinusite". Resultados: Os títulos e resumos potencialmente relevantes pesquisados foram relacionados a 294 artigos, 104 dos quais foram excluídos por falta de critérios de inclusão no estudo. Por fim, 11 artigos foram incluídos na análise final. Sinusite pós-operatória foi encontrada em 78 pacientes em 9 artigos entre 1195 pacientes. A falha do implante foi relatada em 136 casos e a perfuração da membrana sinusal em 185 seios, em 11 artigos, entre 1372 procedimentos de elevação sinusal. Conclusão: Os achados mostraram que os fatores de risco para sinusite após cirurgia de implante foram ruptura da membrana Schneideriana e sinusite pré-operatória, assim como tabagismo e altura óssea residual, os quais foram considerados parâmetros que elevaram o risco de falha do implante dentário.

\section{PALAVRAS-CHAVE}

Sinusite; Implantes dentários; Falha, implante. 


\section{INTRODUCTION}

$\mathrm{D}$ ental implantation is globally fulfilled by various approaches along with the rapid advancement in the implantation technology [1]. The mandibular implants are stable support for maxillary implant insertion to be used as a solid base for implantation when maxillary thinning [2]. Prior to maxillary sinus implantation, it should be controlled by the elevation of maxillary sinus mucosa via the sinus lift procedure [3]. During the maxillary implants, the maxilla is thickened by bone grafts as bone transplantation in the presence of excessive maxillary pneumatization [4], thereby increasing the dental implant success rate [5]. The dental implant-induced chronic maxillary sinusitis can occur due to some reasons, such as oroantral fistula organization, postoperative ostial obliteration, the implant-stimulated sinus penetration, foreign body reactioncaused dental implant or bone graft dislocation, unwanted graft infection, preoperative chronic rhinosinusitis and Schneiderian membrane perforation. Endoscopic sinus surgery owing to its satisfactory prognosis and low complication is considered as the first line of surgical procedure [6]. Implant failure is often reported despite efforts in recent years. The purpose of this study was to review the factors leading to side effects in dental implantation of the maxillary sinus.

\section{MATERIAL AND METHODS}

The PRISMA statement was used to design and implement the current systematic review and meta-analysis. Systematic review of selected 11 articles was evaluated to draft the study protocol. The initial search results were recorded in a preprepared data extraction forms.

\section{Search strategy}

The systematic search was performed on electronic databases of MEDLINE, PubMed, Cochrane Library, Embase, ISI, Google scholar to find corresponding articles regarding dental literature during 2010 to 2019. Electronic title management was carried out by Endnote X9 software. Searches were based on the keywords of "dental implants", "Implants"," dental"," maxilla", "sinusitis".

\section{Study inclusion and exclusion criteria}

The study inclusion criteria included:

1. Dichotomous data of articles properly reported on sinusitis before and after surgery

2. Dichotomous data of articles properly reported on implant failure before and after surgery

3. Dichotomous data of articles properly reported on sinus membrane perforation before and after surgery

4. Data of articles properly reported on sinusitis and dental implants

\section{All language}

The study exclusion criteria included:

\section{Case reports or case series}

2. Review articles

3. Articles containing questionnaire data

4. Correct target contents with no data reporting

\section{Studies related to animal experiments} analysis

Extraction of data and method of

The required data were extracted according to author names, study design, observation period, publication year, number of procedures, patients, sinusitis, dental implant failures and Follow-up. Random effects model was used for data analysis and calculation of summarized ORs with 95\% confidence interval (95\% CI) and considering interand intra-study variance. Comprehensive MetaAnalysis Stata V14 software was performed to analyze heterogeneity (I2) of RCTs, meta-analysis (weighted mean difference 95\%CI) and forest plots.

\section{RESULT}

The searched potentially relevant titles and abstracts were related to 294 articles. In the first selection phase, 81 articles were excluded due to irrelevance of titles and abstracts. In the second selection phase, the full-text of remaining 213 articles was reviewed. Totally, 104 articles were excluded due to lack of study inclusion criteria. At last, 11 articles were included into the final analysis (Figure 1). Individual studies enrolled in this meta-analysis are shown in Table I. 


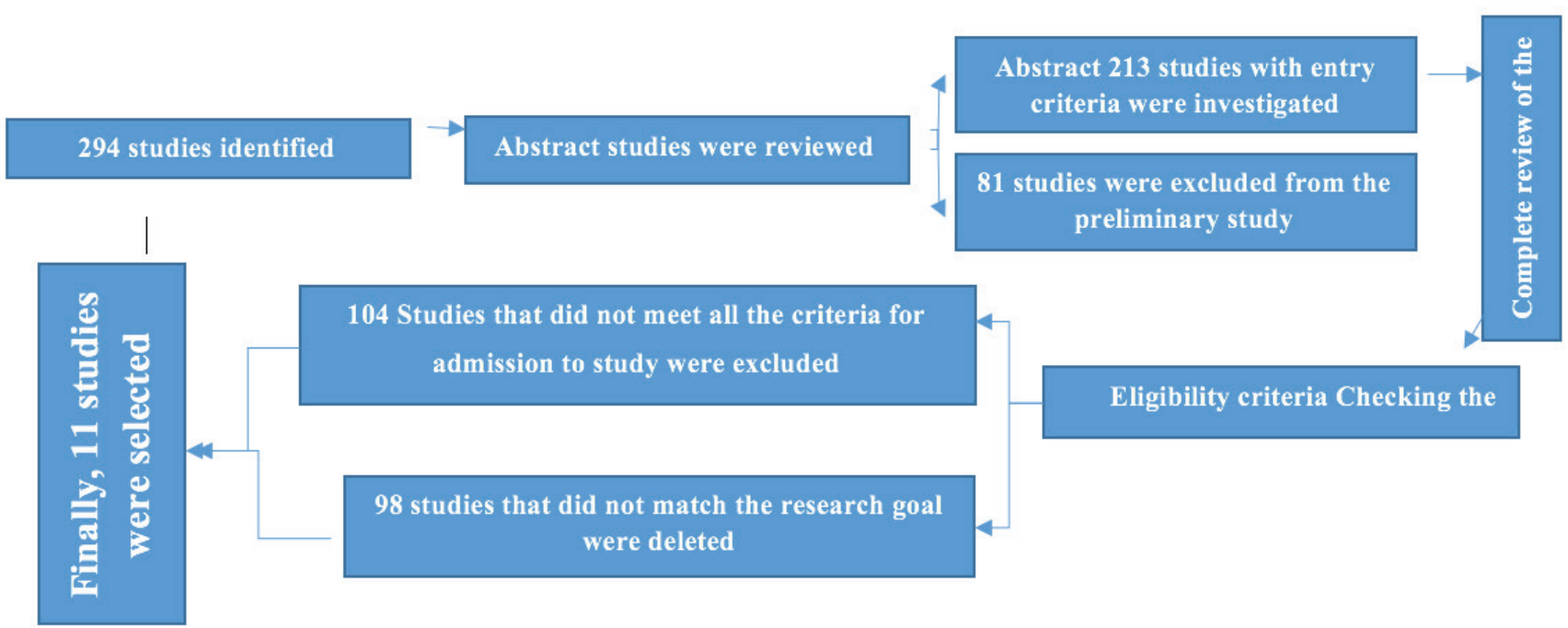

Figure 1 - Flowchart for the study selection.

Table I - Demographics of individual studies in this meta-analysis

\begin{tabular}{|c|c|c|c|c|c|c|c|c|}
\hline Authors & Methodology & $\begin{array}{l}\text { Duration of Follow-up, } \\
\text { Month }\end{array}$ & $\begin{array}{l}\text { Total No.of } \\
\text { Patients }\end{array}$ & Sinusitis & $\begin{array}{l}\text { Perforation of } \\
\text { Sinus Membrane }\end{array}$ & $\begin{array}{l}\text { Total No. of } \\
\text { Sinuses }\end{array}$ & $\begin{array}{l}\text { Implant } \\
\text { Failure }\end{array}$ & $\begin{array}{l}\text { Total No. of } \\
\text { Implants }\end{array}$ \\
\hline Chen et al[6],2018 & $\begin{array}{l}\text { Prospective cohort } \\
\text { study }\end{array}$ & 36 & 84 & 6 & 6 & NA & 0 & NA \\
\hline Kozuma et al[7],2017 & Observational study & 60 & 109 & NA & 18 & 121 & 8 & 252 \\
\hline Chirila et al[8],2016 & Retrospective study & 36 & 116 & 5 & 1 & 151 & 5 & 245 \\
\hline Guerrero et al[9],2015 & Retrospective study & NA & 68 & NA & 13 & 101 & 16 & 141 \\
\hline Vazquez et al[10], 2014 & Retrospective study & 108 & 127 & 6 & 52 & 202 & 9 & 364 \\
\hline Soardi et al[11],2013 & Retrospective study & 216 & 256 & 0 & 3 & 323 & 19 & 376 \\
\hline Borges et al,[12],2011 & Prospective study & 12 & 15 & 2 & 2 & 30 & 1 & 53 \\
\hline Kim etal[13],2013 & Retrospective study & 72 & 259 & 33 & 90 & 338 & 69 & 643 \\
\hline Kim etal[14],2014 & Retrospective study & 48 & 60 & 5 & 17 & 65 & 9 & 65 \\
\hline Nolan et al[15],2014 & Retrospective stud & 48 & 208 & 20 & 150 & 359 & 24 & 359 \\
\hline Kim et al[16],2012 & Prospective study & NA & 70 & 1 & 2 & 70 & 0 & 70 \\
\hline
\end{tabular}

Postoperative sinusitis was found in 78 patients within 9 articles among 1195 patients (Figure 2). The sinus membrane perforation was reported in 185 sinuses (Figure 3 ) and the implant failure in 136 cases (Figure 4) within 11 articles among 1372 sinus lift procedures.

In conditions affecting postoperative sinusitis, 2 studies with sample size of 323 were related to preoperative sinusitis (Figure 5A), 4 studies with sample size of 644 were related to intraoperative Schneiderian membrane perforation (Figure 5B), 2 studies with sample size of 236 were related to smoking and diabetes mellitus (Figure 5C and Figure 5E), 1 study with sample size of 109 was related to sex and coexistence of dental implant surgery (Figure 5D and Figure 5F). 


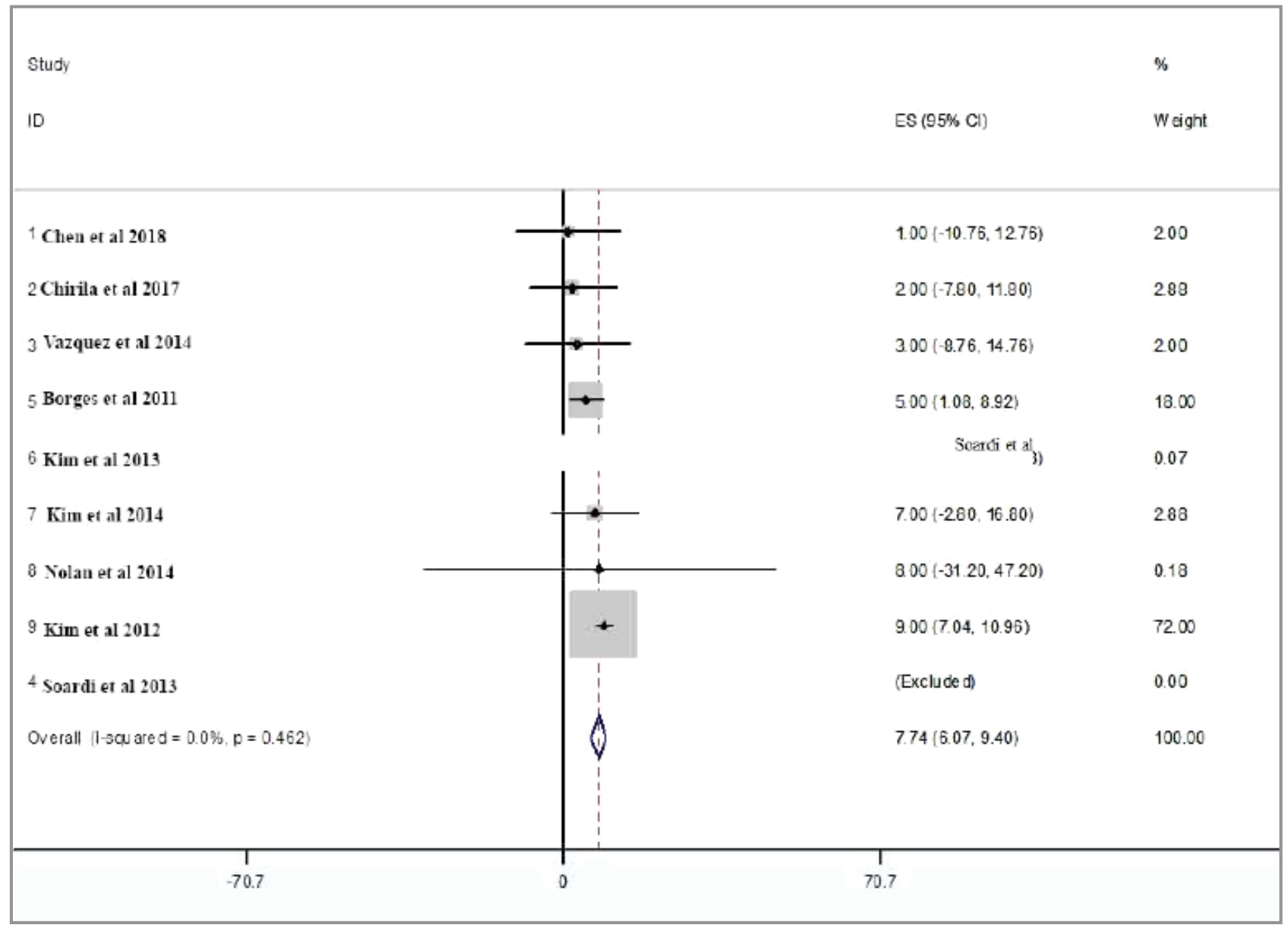

Figure 2 - Overall rates of postoperative sinusitis

Heterogeneity chi-squared $=6.69($ d.f. $=7) p=0.462$

I-squared (variation in ES attributable to heterogeneity) $=0.0 \%$

Test of ES=0: $z=9.12 p=0.000$. 


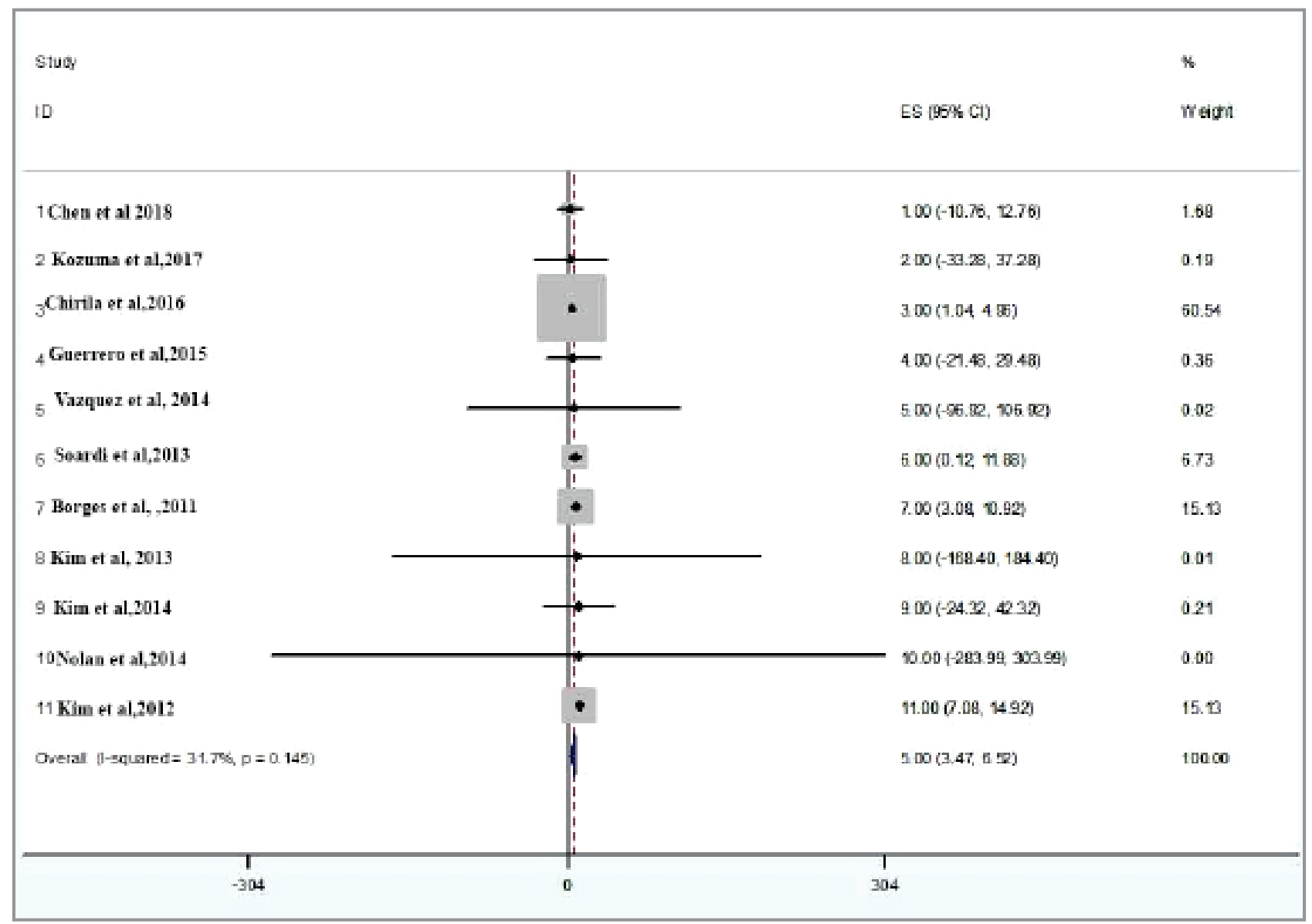

Figure 3 - Perforation of the Schneiderian membrane

Heterogeneity chi-squared $=14.65$ (d.f. $=10) p=0.145$

I-squared (variation in ES attributable to heterogeneity) $=31.7 \%$

Test of ES=0: $z=6.43 p=0.000$ 


\begin{tabular}{|c|c|c|}
\hline Study & & $\%$ \\
\hline ID & $\mathrm{ES}(95 \% \mathrm{Cl})$ & Weight \\
\hline 2 Kozuma et al,2017 & $2.00(-13.68,17.68)$ & 1.43 \\
\hline 3 Chirila ot al, 2016 & $3.00\{-6.80,12.80\}$ & 3.67 \\
\hline 4 Guertero et al,2015 & $4.00\{-27.36,35.36\}$ & 0.36 \\
\hline 5 Vazquez et al, 2014 & $5.00(-12.64,22.54)$ & 1.13 \\
\hline 6 Soardie er al,2013 & $6.00(-31.24,43.24)$ & 0.25 \\
\hline 7 Borges et al, .2011 & $7.00(5.04,6.96)$ & 91.60 \\
\hline 8 Kim et al, 2013 & $8.00\{-127.24,143.24\}$ & 0.02 \\
\hline 9 Kim et aL,2014 & $9.00\{-8.64,26.64\}$ & 1.13 \\
\hline 10 Nolan et al,2014 & $10.00(-37.04,57.04)$ & 0.16 \\
\hline 1 Chen er al 2018 & (Excluded) & 0.00 \\
\hline $11 \mathrm{Kim}$ et al.201? & (Excluded) & 0.00 \\
\hline Oraral (i-squared $=0.0 \%, p=0.997)$ & $6.77(4.89,8.65)$ & 10000 \\
\hline $\begin{array}{r}1 \\
-143 \\
\end{array}$ & 13 & \\
\hline
\end{tabular}

Figure 4 - Perforation of the failure of dental implant

Heterogeneity chi-squared $=1.13($ d.f. $=8) p=0.997$

I-squared (variation in ES attributable to heterogeneity) $=0.0 \%$

Test of ES=0:z=7.07 $p=0.000$ 

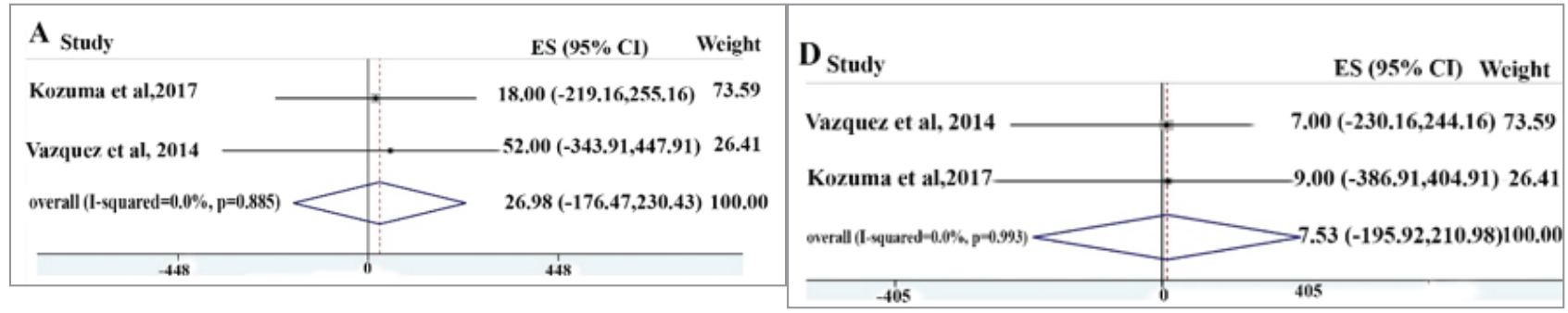

\begin{tabular}{|c|c|c|}
\hline B Study & ES $(95 \%$ CI) & Weight \\
\hline Kim et al, 2013 & $1.00(-508.63,508.63)$ & 4.40 \\
\hline Nolan et al,2014 & $2.00(-405.67,409.67)$ & 6.83 \\
\hline Guerrero et al,2015 & $3.00(-130.28,136.28)$ & 24.87 \\
\hline Kozuma et al,2017 & $4.00(-209.64,217.64)$ & 63.90 \\
\hline overall (1-squared $=0.0 \%, p=1.000)$ & $3.09(-103.44,109.63)$ & 100.00 \\
\hline-509 & 509 & \\
\hline
\end{tabular}
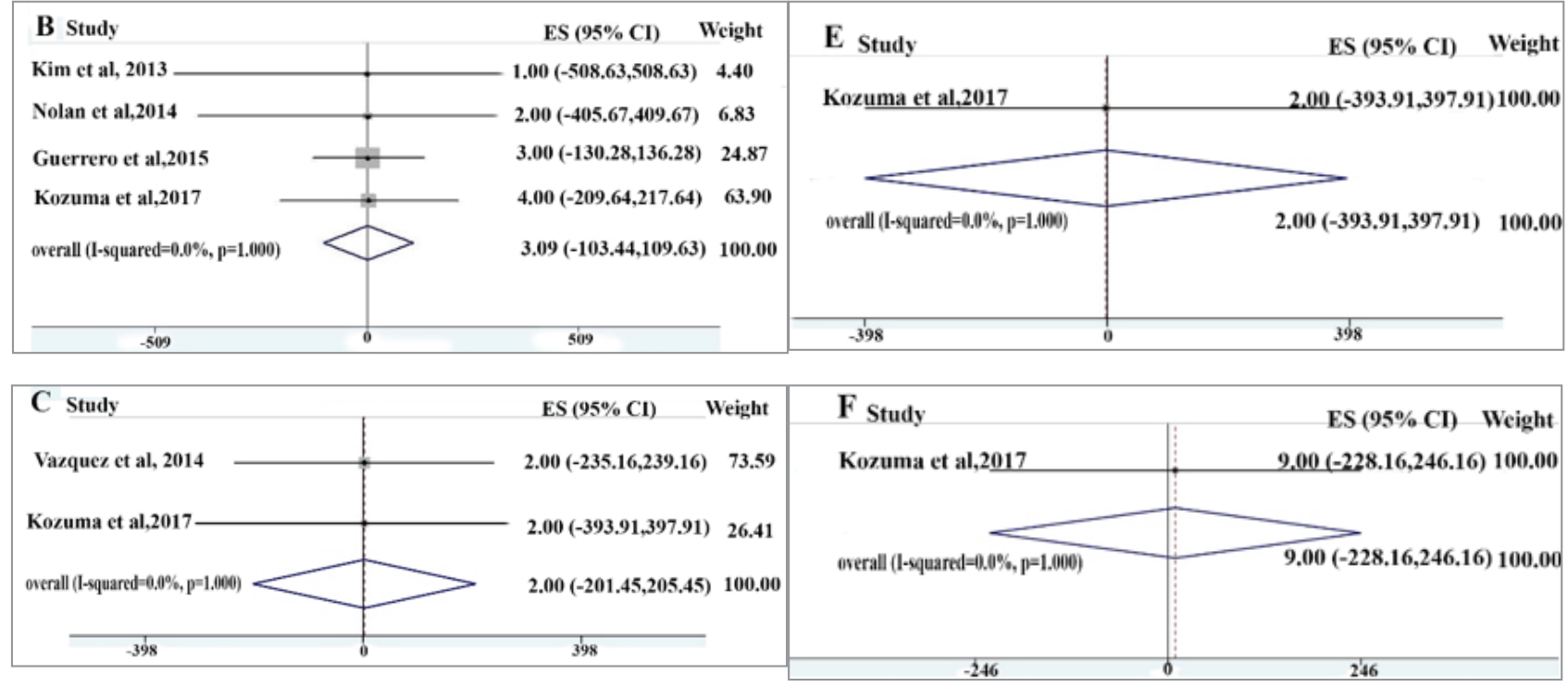

Figure 5 - Forest plots showing the relationship between postoperative sinusitis and each of the following primary outcomes: A: preoperative sinusitis, B: perforation of the Schneiderian membrane, C: smoker, D: diabetes mellitus, E: sex, F: simultaneity of dental implant surgery. 

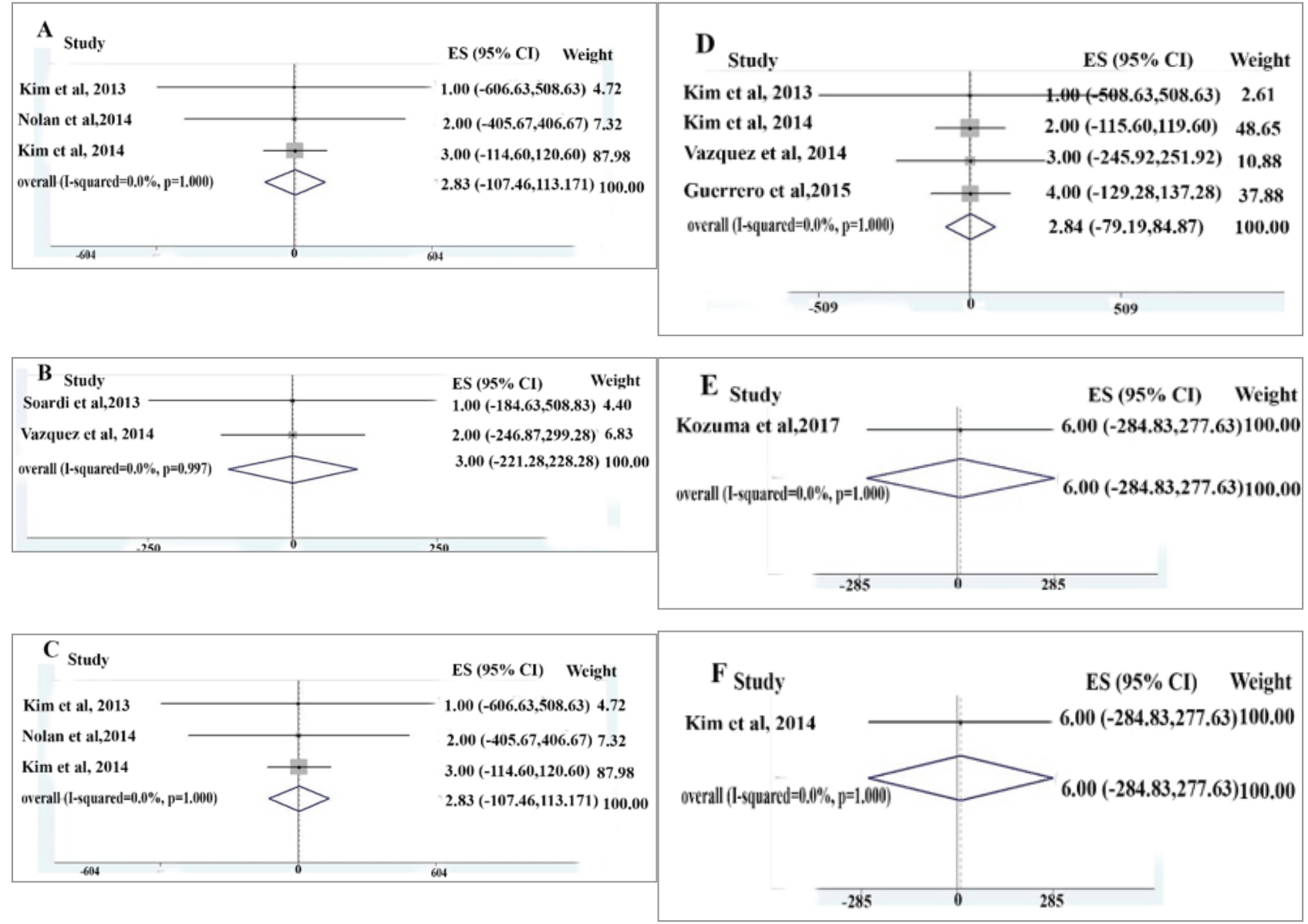

Figure 6 - Forest plots showing the relationship between dental implant and each of the following primary outcomes: A: perforation of the Schneiderian membrane, B: smoker, C: sex, D: dental implant surgery, E: surgical approach for dental implantation, F: age.

3 studies with sample size of 527 were related to intraoperative Schneiderian membrane perforation (Figure 6A), 2 studies with sample size of 383 were related to smoking (Figure 6B), 3 studies with sample size of 527 were related to sex (Figure 6C), 4 studies with sample size of 595 were related to co-existence of dental implant surgery (Figure 6D), 1 study with sample size of 109 was related to surgical procedure (Figure 6E), and other study with sample size of 60 were related to age (Figure $6 \mathrm{~F})$.

The postoperative sinusitis was affected only by intraoperative Schneiderian membrane perforation and preoperative sinusitis, but not by gender and smoking. The dental implant failure was affected only by maxillary residual bone height and smoking.

\section{DISCUSSION}

According to the findings from our analysis, the total incidence rate of postoperative sinusitis was estimated at $3 \%$, and the total incidence rate of dental implant failure was $5 \%$. It should be noted that the presence or absence of postoperative sinusitis was shown to be significantly influenced by the preoperative sinusitis. Moreover, the total incidence rate of sinus membrane perforation was calculated to be $17 \%$. Our results revealed that the risk of sinusitis was reduced significantly in the absence of Schneiderian membrane perforation. The smoking may not significantly trigger sinusitis, but many inflammatory responses like marginal bone loss and peri-implantitis may develop the implant failure [10]. The smoking can reportedly 
slow down the wound healing probably due to implant failure, in line with our findings [17]

Implant loss and postoperative infection can occur in the presence of sinus augmentation via a lateral open approach because of preoperative chronic sinusitis [18].

In a study of Fabbro et al., the survival rate of dental implants co-inserted by sinus augmentation cannot be influenced by preoperative maxillary sinus pathology [18] such as mucosal thickening (61.4\%) found in 35 patients [19]. An otolaryngologist should deal with the elimination of adverse effects, such as rhinosinusitis, after dental implantation and the consideration of preventative actions prior to the implantation [20]. Pignataro et al. recommended three stages for a successful otolaryngologist while performing the sinus lift procedure, including preventative diagnosis, preventative therapy and diagnostic therapy [20].

The maxillary sinus develops postoperative hematoma or edema, hereby resulting in natural maxillary sinus ostial blocking and thus developing the sinusitis [7]. In accordance with the reports of Chen et al. [6], the medical therapy can sufficiently used to treat the chronic change-free sinusitis, in line with the present findings. Reportedly, the smoking interferes with leukocyte phagocytic adherence and chemotaxis as well as elevates the level of cytokines like interleukin. However, no definitive conclusions are available regarding the decreasing or increasing effect of smoking on postoperative sinusitis during dental implantation [10, 21-23].

\section{CONCLUSION}

The findings showed that the risk factors of sinusitis after implant surgery were Schneiderian membrane rupture and preoperative sinusitis, as well as smoking and residual bone height were the parameters elevating the dental implant failure risk.

\section{REFERENCES}

1. Liberati A, Altman DG, Tetzlaff J, Mulrow C, Gøtzsche PC, loannidis JP, et al. The PRISMA statement for reporting systematic reviews and meta-analyses of studies that evaluate health care interventions: explanation and elaboration. PLoS Med. 2009 Jul 21;6(7):e1000100. doi:10.1371/journal.pmed.1000100. Epub 2009 Jul 21.

2. Westover LM. Evaluation of the interface mechanical properties of craniofacial implants and natural teeth through development of the Advanced System for Implant Stability Testing (ASIST) [Thesis]. University of Alberta;2016.

3. López-Quiles J, Melero-AlarcónC,Cano-Duran J, Sánchez-Martínez-Sauceda E, Ortega R. Maxillary sinus balloon lifting and deferred implantation of 50 osseointegrated implants: a prospective, observational, non-controlled study. Int J Oral Maxillofac Surg.2018 0ct;47(10):1343-1349. doi: 10.1016/j. ijom.2018.04.014. Epub 2018 May 24.

4. Aghaloo TL, Misch C, lacono VJ, Wang H-L. Bone Augmentation of the Edentulous Maxilla for Implant Placement: A Systematic Review. Int J Oral Maxillofac Implants. 2016;31 Suppl:s19-30. doi: 10.11607/jomi.16suppl.g1.

5. Chrcanovic BR, Kisch J, Albrektsson T, Wennerberg A. Survival of dental implants placed in sites of previously failed implants. Clin Oral Implants Res. 2017 Nov;28(11):1348-1353. doi:10.1111/clr.12992. Epub2016 0ct 14.

6. Chen YW, Lee FY, Chang PH, Huang CC, Fu CH, Huang CC, et al. A paradigm for evaluation and management of the maxillary sinus before dental implantation. Laryngoscope. 2018 Jun;128(6):1261-1267. doi: 10.1002/lary.26856. Epub 2017 Sep 16.

7. Kozuma A, Sasaki M, SekiK, Toyoshima T, Nakano H, Mori Y.Preoperative chronic sinusitis as significant cause of postoperative infection and implant loss after sinus augmentation from a lateral approach. Oral Maxillofac Surg. 2017 Jun;21(2):193-200. doi: 10.1007/s10006-017-0611-8. Epub 2017 Mar 22.

8. Chirilă L, Rotaru C, FilipovI,Săndulescu M. Management of acute maxillary sinusitis after sinus bone grafting procedures with simultaneous dental implants placement-a retrospective study. BMC Infect Dis. 2016 Mar 8;16 Suppl 1:94. doi:10.1186/s12879-016-1398-1.

9. Guerrero JS. Lateral window sinus augmentation: Complications and outcomes of 101 consecutive procedures. Implant Dent. 2015 Jun;24(3):354-61. doi: 10.1097/ID.0000000000000250.

10. Vazquez JCM, de Rivera ASG, Gil HS, Mifsut RS. Complication rate in 200 consecutive sinus lift procedures: guidelines for prevention and treatment. J Oral Maxillofac Surg. 2014 May;72(5):892-901. doi:10.1016/j.joms.2013.11.023. Epub2013Dec2.

11. Soardi E,CosciF,Checchi V,Pellegrino G, Bozzoli P,Felice P.Radiographic analysis of a transalveolar sinus-lift technique: a multipractice retrospective study with a mean follow-up of 5 years. J Periodontol. 2013 Aug;84(8):1039-47. doi:10.1902/jop.2011.100684.

12. BorgesFL, Dias RO, Piattelli A, Onuma T,Gouveia Cardoso LA, Salomão $M$, et al. Simultaneous sinus membrane elevation and dental implant placement without bone graft: a 6 month follow up study. J Periodontol. 2011 Mar;82(3):403-12. doi:10.1902/jop.2010.100343. Epub2010 Nov 8.

13. Kim YK, Hwang JY,Yun PY. Relationship between prognosis of dental implants and maxillary sinusitis associated with the sinus elevation procedure. Int J Oral Maxillofac Implants. 2013 Jan-Feb;28(1):178-83. doi: 10.11607/jomi.2739.

14. Kim YK, Ahn KJ, Yun PY. A retrospective study on the prognosis of single implant placed at the sinus bone graft site. Oral Surg Oral Med Oral Pathol Oral Radiol. 2014 Aug;118(2):181-6. doi: 10.1016/j.0000.2013.05.011. Epub 2013 Jul 6. 
15. Nolan PJ, Freeman K, Kraut RA. Correlation between Schneiderian membrane perforation and sinus lift graft outcome: a retrospective evaluation of 359 augmented sinus. J Oral Maxillofac Surg. 2014 Jan;72(1):47-52. doi: 10.1016/j. joms.2013.07.020. Epub2013 Sep24.

16. Kim DY,Itoh Y,Kang TH. Evaluation of the Effectiveness of a Water Lift System in the Sinus Membrane Lifting Operation as a Sinus Surgical Instrument. Clin ImplantDent RelatRes. 2012 Aug;14(4):585-94. doi: 10.1111/.1.17088208.2010.00292.x. Epub2010 Jun 25.

17. Kim JS, Choi SM, Yoon JH, Lee EJ, Yoon J, Kwon SH, etal. What Affects Postoperative Sinusitis and Implant Failure after Dental Implant: A Meta-analysis. Otolaryngol Head Neck Surg. 2019 Jun;160(6):974-984. doi: 10.1177/0194599819829747. Epub 2019 Feb 19.

18. Manor Y,Mardinger O, Bietlitum I,Nashef A, Nissan J, Chaushu G. Late signs and symptoms of maxillary sinusitis after sinus augmentation. Oral Surg Oral Med Oral Pathol Oral Radiol Endod. 2010 Jul;110(1):e1-4. doi:10.1016/j. triple0.2010.02.038.

19. KüçükkurtS. Evaluation of the survival of implant placement simultaneously with sinus augmentation: relationship in maxillary sinus pathologies. Oral Radiol. 2019 Jul 12. doi: 10.1007/s11282-019-00399-w. [Epub ahead of print]
20. Pignataro L, Mantovani M, Torretta S, Felisati G, Sambataro G. ENT assessment in the integrated management of candidate for (maxillary) sinus lift. Acta Otorhinolaryngol Ital. 2008 Jun;28(3):110-9.

21. Huang $\mathrm{CC}$, Wang $\mathrm{CH}$, Fu CH, Huang CC, Chang PH, Chen YW, et al. Association between cigarette smoking and interleukin-17A expression in nasal tissues of patients with chronic rhinosinusitis and asthma. Medicine (Baltimore). 2016 Nov;95(47):e5432

22. Strzelak A, Ratajczak A, Adamiec A, Feleszko W. Tobacco smoke induces and alters immune responses in the lung triggering inflammation, allergy, asthma and other lung diseases: a mechanistic review. Int J Environ Res Public Health. 2018 May 21;15(5). pii:E1033. doi:10.3390/ijerph15051033.

23. Christensen DN, Franks ZG, McCrary HC, Saleh AA, Chang EH. A systematic review of the association between cigarette smoke exposure and chronic rhinosinusitis. Otolaryngol Head Neck Surg. 2018 May;158(5):801-816. doi: 10.1177/0194599818757697. Epub2018Feb20.

\section{Samira Jamali}

\section{(Corresponding address)}

Department of Endodontics, Stomatological Hospital, College of Medicine, Xi'an Jiaotong University, Shaanxi 710004, PR China

E-mail: samira.jamali90@yahoo.com

Date submitted: 2019 Nov 05 Accept submission: 2020 Jan 31 